Wangenge-Ouma, G. (2012). Tuition fees and the challenge of making higher education a popular commodity in South Africa. HIGHER EDUCATION, OnlineFirst, April 28.

Tuition fees and the challenge of making higher education a popular commodity in South Africa

\title{
Gerald Wangenge-Ouma
}

Faculty of Education, University of the Western Cape, Private Bag X17, Bellville, 7535

\begin{abstract}
The funding of higher education in South Africa has in the recent past been a subject of animated debate. This debate has ranged from the adequacy of government funding of higher education, the suitability of the funding framework, to protestations against frequent tuition fee increases. At present, the debate is mainly about "free" higher education. Unlike most African countries, South Africa has an established history of cost sharing. But, for a while now, students, especially Black students, have been demanding tuition free higher education even though the country has a student financial aid scheme to support talented but poor students. The demands for tuition free higher education suggest, among others, the possible existence of financial barriers to higher educational opportunities. This paper is a sequel to the debate on free higher education in South Africa. It seeks, in the main, to understand and examine the rationale and drivers for the students' demand for "free" higher education. What are the financial barriers to higher educational opportunities that the current funding architecture has failed to address? Secondly, why are students demanding free higher education when there is a scheme to support talented but poor students? Is cost sharing inconsistent with the country's postapartheid transformation policy in higher education? Finally, is "free" higher education the panacea to the access and participation challenges facing Black students?
\end{abstract}

\section{Keywords}

Free higher education, tuition fees, cost-sharing, access, equity.

\section{Introduction}

A curious development is happening in South Africa where debate on funding higher education has, in the recent past, been particularly animated. This debate has ranged from the adequacy of public funding of higher education (DHET, 2010; Letseka et al. 2010; HESA, 2008; Steyn \& de Villiers 2006; Wangenge-Ouma \& Cloete, 2008); the suitability of the funding framework (DHET, 2010; Wangenge-Ouma, 2010); to protestations against frequent tuition fee increases (DoE 2007, 2006; HESA, 2008; Wangenge-Ouma \& Cloete, 2008; Wangenge-Ouma, 2010). 
At present, the debate is mainly about "free" higher education (FHE). Unlike most African countries, South Africa has an established history of cost sharing. Following the demise of apartheid, the country embarked on a trajectory of transformation. In higher education, a new 'transformative' higher education funding framework was developed including a student financial aid scheme. But for a while now, students, especially Black students, have been demanding FHE; suggesting, inter alia, that the existing funding mechanisms do not sufficiently address financial barriers to higher educational opportunities. This paper seeks to carry forward the ongoing debate on FHE in South Africa by, inter alia, attempting to understand and examine the rationale and drivers for the students' demands for FHE. Why are students demanding FHE when there is a scheme to support talented but poor students? Is cost sharing inconsistent with the country's post-apartheid higher education transformation policy? Finally, is FHE the solution to the access and participation challenges facing Black students?

\section{Access to higher education in South Africa}

Bunting \& Cloete (2008: 1) aptly point out that "[a]ccess to higher education has been a prominent issue on the national political agenda and a central "driver" of higher education policy for both the apartheid and the post-apartheid governments." Consistent with apartheid's philosophy of "separate development", access to higher education by non-white communities, especially the African population group, was naturally neglected as reflected, inter alia, in the pre-dominant apartheid era higher education funding mechanisms, which did not regard equity of access as an important higher education funding consideration (Wangenge-Ouma 2010).

The collapse of apartheid in 1994 was followed by a deliberate attempt to mitigate its effects. The policy of transformation by the post apartheid state, meant mainly to address apartheid's inequities, is strongly reflected in South Africa's new higher education funding framework, which among others, privileges equity of access, especially with regards to disadvantaged communities. Funding is probably the most important tool that was utilised by the apartheid state, and is being utilised by the post apartheid state, to achieve the desired access policy goals. The use of funding mechanisms to achieve particular access goals is not surprising. It is generally agreed that the funding of higher education is intricately linked with issues of accessibility (Teixeira et al. 2006, Johnstone and Marcucci 2010).

Partly due to funding-related interventions, including the National Student Financial Aid Scheme (NSFAS) introduced in 1996, enrolments in South Africa's higher education generally reflect an expanded access to higher education by previously marginalised communities. A summary of the changes in student enrolment totals in South Africa's public higher education system in the past two decades $(1986$ - 2005) is captured in Figure 1 overleaf. As shown in the graph, the period $1986-1994$ experienced a significant increase in enrolments, and in the 1995 - 1999 period enrolment growth levelled off. Enrolment growth increased rapidly again between 2000 and 2004. 
Figure 1: Enrolments in South Africa's higher education, 1985 - 2005

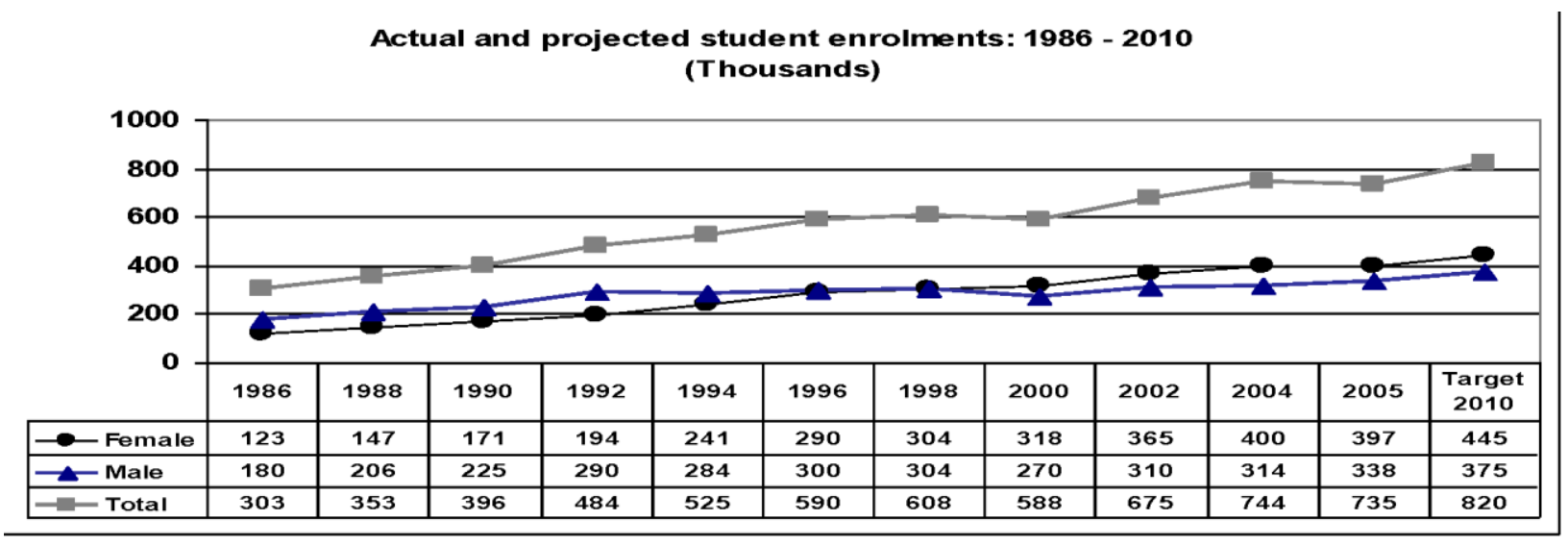

Source: Bunting and Cloete (2008).

Enrolments by race group changed markedly over this 20-year period, as can be seen in Figure 2 below. In 1986, White students had a $60 \%$ share, and African students a $27 \%$ share, of total higher education enrolments. In 2005, the African student share of the total enrolment was $62 \%$ and that of White students, $25 \%$.

Figure 2: Enrolments in South Africa's higher education by race, 1985 - 2005

Head count enrolments by race group: 1986- 2004

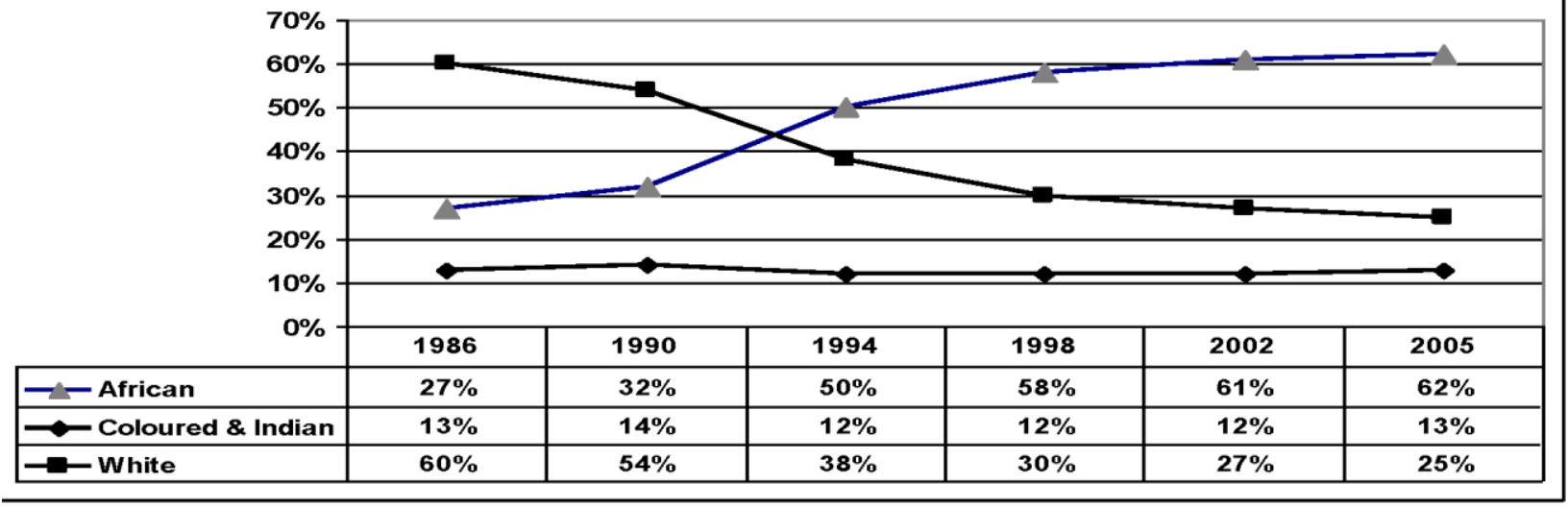

Source: Bunting and Cloete (2008).

Figure 3 below shows participation rates by population groups over a twenty year period. The gross higher education participation rate is calculated based on the total headcount enrolment in each year and the total population in the $20-24$ age group. Although participation has generally increased, participation rates by the various population groups are generally disproportionate to their population size; the African population group being the most underrepresented. While accounting for about $80 \%$ of the total South African population, its higher education participation rate is $12 \%$ compared, for 
example, to the White population group with a $60 \%$ participation rate, but an overall population representation of only $9 \%$.

Figure 3: Gross participation rates by population group, 1986 - 2005

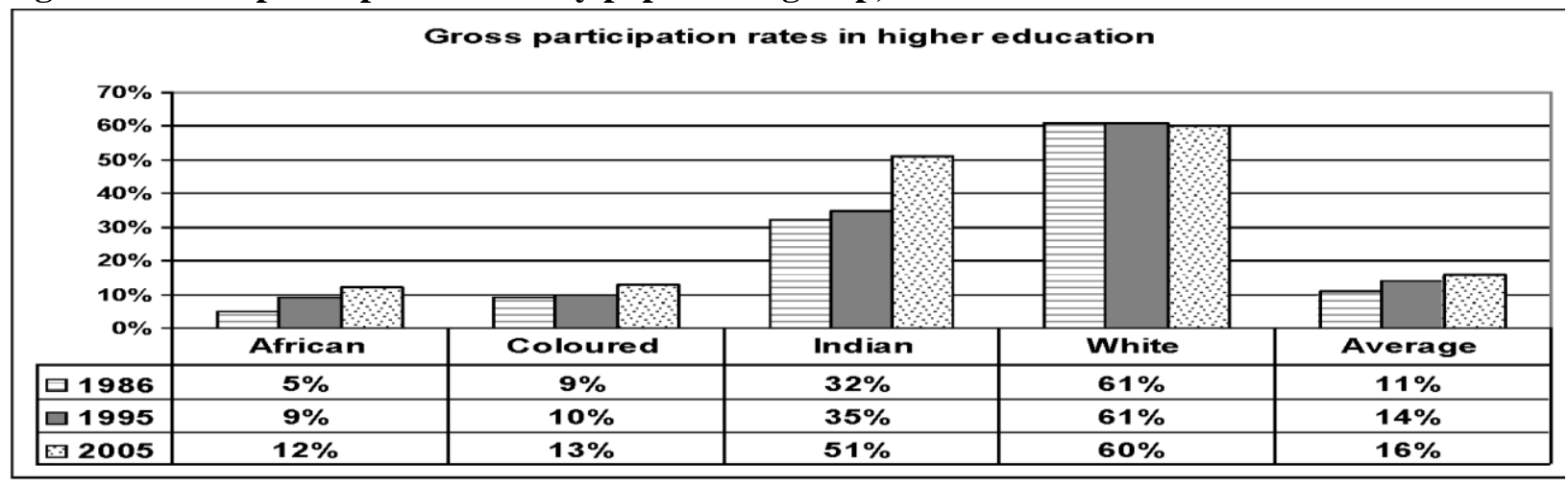

Source: Bunting and Cloete (2008).

Access to and participation in South Africa's higher education is further hampered by high levels of internal inefficiencies, especially drop outs. Cosser \& Letseka (2010: 3) quoting DoE (2005), report that of the 120000 students who enrolled in higher education in 2000, 36000 (30\%) dropped out in their first year of study. A further 24000 (20\%) dropped out during their second and third years of study. Of the remaining 60000 (50\%), fewer than half (22\%) graduated within the specified three-year period. A recent report by the Department of Higher Education and Training (DHET) (2010), states that $48 \%$ of NSFAS beneficiaries (316320) have dropped out or otherwise have not completed their studies. Various studies have shown that drop outs affect the Black population group the most (Letseka et al. 2010). Bhorat, Mayet \& Visser (2010) claim there is a 50\% probability for African males to drop out of university compared to graduating.

Other than dropping out, general access remains a major challenge. A recent study by Cloete (2009) shows that out of the 5756003 people South Africa has in the $18-24$ age cohort $41.6 \%$ are not employed, not in education and training yet about $27 \%$ of these, about 770000 , have the requisite academic qualifications to attend tertiary education institutions (Cloete, 2009).

Overall, higher education access and participation in South Africa is problematic. Being one of the most unequal societies in the world with the Gini coefficient increasing from 0.64 in 1995 to 0.72 in 2005 (Bhorat, Van der Westhuizen \& Jacobs, 2009), the current access and participation patterns can only serve to reproduce these inequalities - as reflected by the low participation and high dropout rates of especially Black South Africans. Although there are many factors responsible for higher education access and participation in South Africa, this analysis limits itself to funding related factors. 


\section{Funding and higher education access}

Even though the post-apartheid state has established mechanisms, especially the NSFAS ${ }^{1}$, to enhance access to, and participation in, higher education by especially (previously) marginalised communities, achieving equitable access and participation largely remains a mirage as evidenced by the participation and internal inefficiency statistics presented in the preceding section.

Bunting \& Cloete (2008:1) tease out three phases of higher education access policies by the postapartheid state, which are related to funding:

The 1995-2000 period characterised by a tension between the popular notion that "more is better", and the Department of Education which concluded that "more" was not affordable, and that the overall policy thrust should be "not more, but more diverse (equity)".

The 2000-2004 period, which as shown in Figure 1, was a period of rapid enrolment growth, in comparison to what had occurred during 1994-2000. Following the rapid enrolment growth, the subsequent policy thrust, as described by Bunting and Cloete (2008), was "more is not better", because these increased enrolments could not be funded adequately and because output efficiencies declined.

$\square$ In the post-2004 period, the pace of student enrolment growth slowed down and the Department of Education began to move towards a system in which enrolment growth is determined by a contract between each institution and the Ministry of Education. Bunting and Cloete (2008:1) describe this period as one of "more, but diverse and differentiated".

The growth in enrolments in the 1995-2004 period required that larger sums of money be set aside to finance this growth. A recent analysis by Ouma (2007) shows that during this period government funding of higher education matched the growth in enrolments - to some extent. Unfortunately, the growth in enrolments was not sustainable, and from 2001 onwards, state allocations to higher education started dipping leading to the "more is not better" policy. The "massification" agenda was effectively discarded in 2004 when the government imposed enrolment caps citing financial constraints as the reason. When introducing the caps, the government argued that

... the [South African] higher education system has grown more rapidly than the available resources. The resultant short-fall in funding has put severe pressure on institutional infrastructure and personnel, thus compromising the ability of higher education institutions to discharge their teaching and research mandate (DoE 2005c: 3).

The introduction of enrolment caps as a way of limiting rapid growth of student enrolments was a clear indication that government funds available for higher education are not infinite. As is well known, the trajectory of public revenues generally does not keep up with the trajectory of higher education cost increases (a function of accelerating increases in student enrolments and per-student costs increasing at rates in excess of the average rate of cost increases in the general economy (Johnstone and Marcucci 2010), due mainly to the intense competition from other competing - and

1 The National Student Financial Aid Scheme (NSFAS) is an income contingent loan and bursary scheme established in 1996. NSFAS allocations are currently based on average cost of study programmes and not the actual cost. This leads to underfunding, hence the inability by some NSFAS beneficiaries to meet their study costs. 
also rapidly increasing public needs such as primary and secondary education, public health, safety and security, public infrastructure, and economic development (Zumeta 2004).

Generally, in post apartheid South Africa, affordability both by the state and individual students (and their families) has been the main militating factor against maintaining wide scale enrolments. As noted in the preceding discussion, public funding for higher education by the state has not kept pace with enrolment pressures and increasing costs of higher education provision. Government allocations per full-time equivalent enrolled student rose in nominal terms by an annual average of 5 per cent between 2000 and 2009, but fell at an average annual rate of 1 per cent in real terms.

Related to declining state funding with implications for access, is the practice by South African universities to regularly increase tuition fees to compensate for inadequate public funding, and the inability by the NSFAS to adequately support financially needy students. DoE (2007) shows that tuition fees per full-time equivalent enrolled student in nominal rands rose at an average annual rate of $12.2 \%$ between 2000 and 2004, and in real terms at an annual average rate of $4.8 \%$. As a result of these increases, tuition fees have become the most important single source of non-government revenue for South Africa's public universities, rising from 24 percent in 2000 to 29 percent in 2005 (Wangenge-Ouma \& Cloete, 2008). Tuition fee increases have had multiple effects, and implications for higher education access. Students have protested the increases, at times violently; their argument being that tuition fee increases make higher education unaffordable for poor students.

The notion of unaffordability is supported by the inability of the NSFAS to provide adequate financial support to deserving students (HESA, 2008; DHET, 2010). The 2008 NSFAS allocation data shows that not a single institution managed to allocate NSFAS funding to cover full cost of study. Only five universities were able to allocate more than $50 \%$ of required funding to cover the full cost of study (DHET, 2010). The South African government has argued that tuition fees increased at a faster rate than NSFAS allocations which impacts on the effectiveness of the scheme for poorer students and their access to higher education (DoE, 2007). A recent report of the ministerial committee on the review of NSFAS contends that:

the growth in funds has not kept pace with the ever-increasing demand. Even a fivefold increase in 10 years leaves NSFAS with a massive funding shortfall. It would probably need to triple its budget to meet even current demand (DHET 2010: $x$ ).

Funding is therefore a key determinant of higher education access in South Africa. The existing funding context - declining government funding, regular tuition fee increases and inadequate NSFAS funding - is one that is arguably inimical to wider access and participation and, therefore, the achievement of equity of access in South Africa's higher education. Thus, the present funding context is one that requires significant interventions. It can therefore be argued that the present demands for free higher education are a plausible consequence of the significant inadequacies of the existing higher education funding regime.

The next section ventures into the FHE debate in South Africa preceded by a preview of the experience with free higher education in Africa. 


\section{Free higher education in Africa}

Many countries in Africa have a history of FHE, with the public purse covering tuition and students' living allowances, teaching, buildings and staff costs. Examples of African countries with a history of FHE include Kenya, Zambia, Mozambique, Nigeria, Burkina Faso, and Egypt. In some of these countries, higher education remains "free" to date. Historically, the policy of FHE was driven by a number of factors, some of which are discussed below.

Mamdani (2006) points out that the university in the immediate post-colonial period was a "developmentalist university". It was viewed as the key engine for spurring African development and, therefore, levying fees was seen as an unnecessary obstruction to the expedited development of person power (Wangenge-Ouma, 2008). For many African governments, economic transformation of the continent was to follow from university education. In the context of huge skills shortages, FHE was considered a useful strategy to expedite indigenous person power formation. In the welfare-dominated postcolonial period, it was argued that unless the state subsidised the highly expensive higher education sector, many students would be unable to benefit from it. Thus, other than expediting skills formation, it was deemed that FHE would ensure equity of access (Wangenge-Ouma, 2008).

Another important factor that made it possible to offer FHE was the small number of students. For instance, in 1964 when Kenya attained political independence, only 571 students were enrolled at the then University College, Nairobi. These included undergraduate, postgraduate and diploma students (Wangenge-Ouma 2008). In 1962, the Federal University of Cameroon had 210 students, while the national University of Rwanda had 130 students (Makulu, 1971). Given the overwhelming local and global support for higher education, resources were made available to support a FHE system.

Other than the above factors, Hughes (1994) argues that FHE policies were a part of several compensatory legitimation strategies utilised by especially weak states in the developing world. The FHE policy, as the case is with other compensatory legitimation strategies, is highly visible and populist. It encourages the perception that the state is providing something the people want (Hughes 1994). Thus, highly subsidised or FHE symbolises the state's apparent commitment to access to higher education despite the extremely regressive nature of the policy. The notion of compensatory legitimation probably explains why despite later severe financial exigencies, many African countries maintained the policy of free higher education.

\section{Free higher education and the crisis of the African university}

FHE probably achieved several of its intended goals, mainly, an expedited production of skilled individuals especially for the civil service and secondary school teachers. Free higher education also had a number of "unintended" consequences some of which later led to the crises that defined the African university beginning the late 1970s. One of these consequences is that it engendered gross inequities. Free higher education reproduced and reinforced colonial and post-colonial inequities with regard to distribution of schools and privilege and therefore beneficiaries of FHE. As is well known, the distribution of (good quality) schools in both the colonial and post-colonial eras was and remains uneven. In many African countries, education patterns in the colonial period were set by missionaries who were unevenly distributed, and colonial authorities who had varying interest in education (Makulu, 1971). Some areas were therefore educationally more privileged than others. In the postindependence era, the skewed missionary and colonial education patterns persisted. As a result, the 
main beneficiaries of FHE came from select regions and ethnic groups, and became the countries' elites, who reproduced the same patterns of inequality.

Another equity related concern with FHE is that whereas higher education was free, lower levels of education were not always free, especially secondary education. As a result, many students who could not afford education at lower levels were left out of higher education. Later, as the quality of public education declined, children of the elite quit public schools for high cost and in some cases, exclusive private schools, only to re-appear for public university education in prestigious programmes - for free. It is argued that for effective and equitable student financing in higher education, in a context of high inequalities, financing and support mechanisms for indigent students at lower levels of the educational system should be provided. The rationale for this perspective is that an equitable student financing scheme for higher education cannot be arrived at until the lower levels enjoy the benefits of an equitable student financing scheme that fosters wide scale access.

As higher education systems on the continent expanded, provision of FHE became increasingly expensive and unaffordable, aided by plummeting economic growth. From the mid 1970s until the 1990s, Africa generally experienced a sustained decline in economic growth. World Bank data shows that after reaching a peak of about US\$ 380 in GDP growth (in 2000 prices) in 1976, the growth of African economies continuously declined, reaching a low of slightly more than US\$ 300 in GDP growth in 1995 (Teal, 2010). The drastic decline in Africa's economic growth had severe implications, inter alia, for social provisioning, including higher education. Notwithstanding the strained economic growth vis a vis the high cost of providing FHE, the policy persisted, leading to gross underfunding of many higher education systems on the continent. The gross underfunding had multiple deleterious consequences some of which continue to hound higher education systems on the continent. Enrolments increased faster than the capacity to plan for and finance the growth often leading to suboptimal conditions for meaningful learning.

Overall, FHE was built on inequitable social structures. As a result, it reproduced and reinforced these inequalities. Attempting to impact equity at university level without corresponding initiatives at lower levels of education is an exercise in futility. As is well known, FHE in highly unequal societies mainly benefits the already privileged who have significant social, cultural and economic capital required to access, participate and succeed in education. Equally, FHE was an expensive project that the poor political economies could hardly afford in the long run. As enrolments grew, more resources were required to support a meaningful university experience. These resources were unfortunately not forthcoming. Consequently, FHE eventually spawned ideal conditions for mediocre higher education.

\section{Quest for free higher education in South Africa}

Globally, the general policy thrust regarding the funding of university education has been a shift from absolute public subsidization to some form of cost sharing. For a number of reasons, many countries that offered FHE such as China, Kenya and the United Kingdom, have since implemented cost sharing policies of one form or another. In cases such as Zimbabwe, USA and South Africa, where cost sharing is an established tradition, the tendency has been shifts from one form of cost sharing to another. 
In the recent past, the case for increasing the level of higher education funding in South Africa has been made by student formations, university leaders, and politicians, among others. At present, the debate seems to be shifting from increasing higher education subsidies to provision of FHE. The case for FHE is based on two main premises: (a) social justice: increasing access for the poor, especially, previously marginalised communities, to university education in the face of increasing tuition fees, and (b) growth externalities. Given South Africa's high levels of skills shortages, FHE is deemed necessary to get human capital investment to efficient levels.

The driving forces for FHE in South Africa are not dissimilar from those discussed above for the rest of the continent, with more or less the same conditions such as large scale inequalities, skewed distribution of schools and skills shortages. The purchase of legitimation cannot also be ruled out as a significant rationale for the push for FHE, especially by politicians. The post-apartheid era is characterised by huge expectations especially by Black South Africans. Given the general dissatisfaction with the present tuition fee regimes by poor students vis a vis the higher education participation inequalities discussed in the first part of this analysis, a policy of FHE is a potentially useful strategy for compensatory legitimation by a government whose "core" constituency is becoming increasingly dissatisfied with service delivery. After all, on the face of it, a policy of FHE would be consistent with the country's overarching post-apartheid policy of transformation and social justice.

In the context of the existing formidable barriers to higher education access and participation, it is believed that FHE is the solution to these conundrums. The thinking is that FHE will spur an increase in the social demand for, and participation in, higher education. In theory, many poor students will be able to access higher education. Higher education will thus become a popular commodity. An expanded participation of the poor in higher education will in effect reduce the unacceptably high levels of inequality in South Africa, and result in many other positive externalities such as mitigating the skills shortages in the country (Wangenge-Ouma \& Cloete, 2008).

But, the question remains: will FHE unlock the door to higher education for poor South Africans? Will it, on its own, counteract the disadvantaging contingencies faced by the many poor Black South Africans? Will FHE be the harbinger for an egalitarian South Africa? How best can higher education, and education generally, be made to counteract inequalities of access and participation in a highly unequal society?

\section{Will free higher education benefit South Africa's poor?}

I will attempt a response to the above question by examining South Africa's social structure generally, and schooling in particular. Assuming that the South African government can afford to provide FHE (the previous discussion on NSFAS and the funding challenges presently facing public higher education suggest otherwise), the question is, who will benefit from such a scheme?

From a Rawlsian notion of justice, educational justice should be interpreted as improving the educational position of the educationally most disadvantaged in society. Inequalities in higher education access and participation in South Africa have been occasioned and sustained by multiple external restraints, among them, financial difficulties but more importantly, existing structures of 
inequality in the country. Removing tuition fee requirements in the context of these structures of inequality will not have a meaningful impact in terms of addressing the higher educational needs of South Africa's poor. As it has happened in other African countries that experimented with FHE, it will instead reinforce existing inequalities.

Some of the structures of inequality in South Africa with severe implications for an equitable participation in higher education are discussed below:

\section{Large scale inequalities}

Since the collapse of apartheid, South Africa has witnessed advances in political transformation, macro-economic reform as well as progress in several areas of national life. These advances notwithstanding, the country remains one of the most unequal in the World. As mentioned earlier, South Africa's Gini coefficient increased from 0.64 in 1995 to 0.72 in 2005 (Bhorat, van der Westhuizen and Jacobs 2009). During the same period, Bhorat and his colleagues found that most of the potential poverty gains of economic growth was eroded by the rising levels of income inequality in the country. In addition, economic growth became less pro-poor over time.

Economic inequalities are equally reflected in education. A 2000 study by the Southern and Eastern Africa Consortium for Monitoring Educational Quality (SACMEQ) found that the intraclass correlation coefficient rho $(\rho)$ - which expresses the variance in performance between schools as a proportion of overall variance was 0.70 for reading and 0.64 for mathematics. These scores show exceedingly high inequalities in performance between schools in South Africa (Van der Berg 2008, 2007). Subsequent international standardized tests have consistently returned unfavorable results for South Africa. In the 2006 Progress in International Reading Literacy Study (PIRLS), South Africa's mean reading score was the lowest out of the 40 participating countries (Taylor and $\mathrm{Yu}, 2009$ ).

The high degree of performance inequality among schools is largely a consequence of differences in educational quality. SACMEQ data on the performance inequalities in South Africa shows the country as having high levels of differentials in performance between high and low socio-economic status groups. The same differentials persist when one compares performance between schools in urban and rural areas (Van der Berg 2008). Van der Berg $(2008,2007)$ concludes that the school system was not yet systematically able to overcome inherited socio-economic disadvantage. Thus, the school system is skewed in favour of urban schools and those in the upper socio-economic quintiles. In terms of population group, the majority of Black pupils attend low quality schools that offer limited possibilities for university access - only 1 percent of African schools are top performing on high school certificate results (National Planning Commission, 2011). Schools serving the poor generally lack a sound educational infrastructure; have high student teacher ratios and many of their teachers tend to be under qualified. The problem of teachers is complex. Recent assessments have shown that trained teachers scored less than the minimum scores expected from the average learner in their own subjects (National Planning Commission, 2011).

South Africa spends considerable amounts of money on education - about $5 \%$ of its GDP. These high expenditures have unfortunately not resulted in an equitable education system offering quality education. Further, the country's education system has among the worst internal inefficiencies on the continent. About $50 \%$ of students drop out before reaching grade 12, the final school year. Clearly, 
South Africa's schooling system fares dismally in promoting social equity. The extreme inequalities in the schooling system have implications for who benefits from a FHE system. The extreme inequalities suggest that for interventions to support large scale participation later in the education process to be successful, they must be implemented earlier.

\section{Performance in university entrance examinations}

Data from the Department of Basic Education (Table 1 below) shows that since 2000, less than 20\% of all candidates who write the National Senior Certificate Examination (final school-leaving examinations) obtain a pass with endorsement which qualifies them automatically for university.

Table 1: National Senior Certificate Examination results by gender, 2000 to 2009

\begin{tabular}{|c|c|c|c|c|c|c|}
\hline \multirow[t]{2}{*}{ Year } & \multirow[t]{2}{*}{ Gender } & \multicolumn{2}{|c|}{ Enrolled in Grade 12} & \multirow{2}{*}{\begin{tabular}{|l|}
$\begin{array}{l}\text { Candidates } \\
\text { who wrote }\end{array}$ \\
Number
\end{tabular}} & \multicolumn{2}{|c|}{$\begin{array}{c}\text { Candidates who passed } \\
\text { with Endorsement }\end{array}$} \\
\hline & & Number & $\%$ & & Number & $\%$ \\
\hline \multirow[t]{3}{*}{2000} & Male & 265184 & $54.50 \%$ & 219725 & 32969 & $15.00 \%$ \\
\hline & Female & 221602 & $45.50 \%$ & 269574 & 35657 & $13.23 \%$ \\
\hline & Total & 486786 & $100.00 \%$ & 489299 & 68626 & $14.03 \%$ \\
\hline \multirow[t]{3}{*}{2001} & Male & 258872 & $54.50 \%$ & 247141 & 36168 & $14.63 \%$ \\
\hline & Female & 216197 & $45.50 \%$ & 202191 & 31539 & $15.60 \%$ \\
\hline & Total & 475069 & $100.00 \%$ & 449332 & 67707 & $15.07 \%$ \\
\hline \multirow[t]{3}{*}{2002} & Male & 274900 & $54.40 \%$ & 238761 & 42886 & $17.96 \%$ \\
\hline & Female & 230492 & $45.60 \%$ & 201335 & 39124 & $19.43 \%$ \\
\hline & Total & 505392 & $100.00 \%$ & 440096 & 82010 & $18.63 \%$ \\
\hline \multirow[t]{3}{*}{2003} & Male & 293470 & $54.50 \%$ & 238761 & 42886 & $17.96 \%$ \\
\hline & Female & 245439 & $45.50 \%$ & 201335 & 39124 & $19.43 \%$ \\
\hline & Total & 538909 & $100.00 \%$ & 440096 & 82010 & $18.63 \%$ \\
\hline \multirow[t]{3}{*}{2004} & Male & 310010 & $54.50 \%$ & 253024 & 44428 & $17.56 \%$ \\
\hline & Female & 258654 & $45.50 \%$ & 214866 & 40689 & $18.94 \%$ \\
\hline & Total & 568664 & $100.00 \%$ & 467890 & 85117 & $18.19 \%$ \\
\hline \multirow[t]{3}{*}{2005} & Male & 343916 & $55.00 \%$ & 275140 & 45028 & $16.37 \%$ \\
\hline & Female & 281893 & $45.00 \%$ & 233041 & 41503 & $17.81 \%$ \\
\hline & Total & 625809 & $100.00 \%$ & 508181 & 86531 & $17.03 \%$ \\
\hline \multirow[t]{3}{*}{2006} & Male & 323380 & $54.30 \%$ & 286355 & 44431 & $15.52 \%$ \\
\hline & Female & 271836 & $45.70 \%$ & 241595 & 41399 & $17.14 \%$ \\
\hline & Total & 595216 & $100.00 \%$ & 527950 & 85830 & $16.26 \%$ \\
\hline \multirow[t]{3}{*}{2007} & Male & 328384 & $54.80 \%$ & 310669 & 45835 & $14.75 \%$ \\
\hline & Female & 271242 & $45.20 \%$ & 253712 & 39619 & $15.62 \%$ \\
\hline & Total & 599626 & $100.00 \%$ & 564381 & 85454 & $15.14 \%$ \\
\hline
\end{tabular}

Source: DoE (2002, 2003, 2004, 2005a, 2005b, 2006, 2008a, 2008c, 2009b) 
The data in the above table, even though quite revealing in terms of the gross inefficiencies in South Africa's school system, mask significant differentials in educational attainment across South Africa's population groups and socio-economic statuses. In terms of population groups, the Economist (January 10 2010) shows that whereas $50 \%$ of White students who write the final school leaving examinations qualify for university admission, only about $10 \%$ of Black students qualify for university admission. In addition, Van der Berg (2008) shows that historically white and Indian schools still outperform black and coloured schools in examinations, a reflection of the country's unfortunate past. Although historically black and previously disadvantaged schools make up $80 \%$ of the country's secondary schools, these schools produce only $20 \%$ of students who qualify for university.

Clearly, inadequate educational progress constrains possibilities for massifying participation of South Africa's poor in higher education. It should be emphasized that FHE can only be available to those who make it through the education pipeline and qualify for university admission.

\section{Conclusion}

The recent report of the ministerial committee on the review of the National Student Financial Aid Scheme (DHET 2010) estimates that the realistic population of poor students in need of NSFAS support is $25 \%$ of the total student population - at most $40 \%$. What this means is that although the present higher education funding architecture in South Africa presents some obstacles to access and participation by many students, there is a significant part of the student population to whom the present financial requirements for access do not represent a challenge. Thus, a blanket FHE policy will, contrary to expectations, have potential negative equity implications. Through taxation, the poor, including the permanently poor, will be made to pay for the education of the rich.

Secondly, access to higher education is a function of many factors, some of which probably more significant than financial barriers caused by tuition fees. It is a known fact that students from socioeconomic groups with more cultural, social and economic capital generally have more enrolment opportunities. Educational opportunities in South Africa remain severely constrained by structural inequalities in the country. Extreme regional disparities in school supply and poor school quality remain a South African reality. In a context of a poor performing school system, attaining equity of access in higher education, even with FHE, is a mirage. FHE will not fix the challenges of schooling and the country's embedded inequalities. Therefore, as pointed out by Johnstone \& Marcucci (2010: 8 $-9)$ :

truly equitable access to higher education also requires compensatory policies and instruments to overcome the effects of economic and social deprivation - for example, poor schools, rural isolation, the absence of educated family or peers, linguistic marginalization, and the like occurring prior to a decision to attend college.

Thirdly, as important as university education is, the case for FHE is not more compelling than the case might be, for example, for guaranteed additional investments in public health, security, improved primary education or the many other high priority public needs. State resources are not infinite and are competed for by other equally important (some even more important than higher education) priorities. Recent developments have shown that the state was struggling to meet the increasing costs of higher education. The South African government recently toyed with the idea of introducing tuition fee caps 
precisely because it was becoming difficult for government to provide sufficient NSFAS funding to match the rise in tuition fees. Prior to toying with the idea of tuition fee caps, government had introduced enrolment caps, again, because of challenges of affordability on its part. Of course the South African government could decide to provide FHE without enhancing funding. As the experience of several African countries has shown, such an approach would be a sure recipe for a mediocre education.

Lastly, it is a known fact that whenever a higher educational system is expanding from elite to a more representational student population, as is the case in South Africa, the new students (that is, those who would not in the recent past have been able to gain admission, but who are now deemed qualified and wish for a chance to continue their education) will be, at least on average, more financially needy than the students in the past who tended to come disproportionately from the more socio-economically elite families (Aduol, et. al. 2010). Consequently, the need for financial assistance will increase at an even faster rate than the rate of increase in student numbers (Aduol, et al. 2010). This is exactly what has happened in South Africa. Unfortunately, the student financial assistance agency, NSFAS, has failed to provide sufficient student loan funds to fully meet the needs of all qualified and deserving students. Insufficient student financial assistance has consequently failed to assure equitable access to university education, hence the calls for FHE. Therefore, reforms to student financing are critical in enhancing access in an expanding system characterised mainly by financially needy students.

\section{References}

Aduol, F., Cheboi, B., Johnstone, B.D., Marcucci, P., Pillay, P. \& Wainaina, G. (2010) Financing university education in Kenya: a report to the Ministry of Higher Education, Science \& Technology. Unpublished report.

Bhorat, H., Mayet, N. \& Visser, M. (2010) Student Graduation, Labour Market Destinations and Employment Earnings. In: Letseka M, Cosser M, Breier M \& Visser, M (Eds). Student Retention and Graduate Destination: Higher education \& labour market access and success. Cape Town: HSRC Press. pp. 97-123

Bhorat, H., Van der Westhuizen, C. \& Jacobs, T. (2009) Income and Non-Income Inequality in PostApartheid South Africa: What are the Drivers and Possible Policy Interventions? DPRU Working Paper 09/138.

Bunting, I., and Cloete, N. (2008) "Governing Access to Higher Education in South Africa." Unpublished paper.

Cloete, N. (Ed.) (2009) Responding to the educational needs of post-school youth: determining the scope of the problem and developing a capacity-building model. Centre for Higher Education Transformation: Cape Town.

Cosser, M. \& Letseka, M (2010) Introduction. In: Letseka M, Cosser M, Breier M \& Visser, M (Eds). Student Retention and Graduate Destination: Higher education \& labour market access and success. Cape Town: HSRC Press. Pp. 1 -9. 
Department of Education (DoE). (2002) Education statistics in South Africa at a glance in 2000. Pretoria: Government Printing Works.

Department of Education (DoE). (2003) Education statistics in South Africa at a glance in 2001. Pretoria.

Department of Education (DoE). (2004) Education statistics in South Africa at a glance in 2002. Pretoria: Government Printing Works.

Department of Education (DoE). (2005a) Education statistics in South Africa at a glance in 2003. Pretoria: Government Printing Works.

Department of Education (DoE). 2005b. Education statistics in South Africa at a glance in 2004. Pretoria: Government Printing Works.

Department of Education (DoE) (2005c) Student enrolment planning in public higher education. Available online at: http://www.edu.gov.za/content/documents/705.pdf (accessed 20 June 2008).

Department of Education (DoE) (2006) Education statistics in South Africa at a glance in 2005. Pretoria: Government Printing Works.

Department of Education (DoE) (2008a) Education Statistics in South Africa at a glance in 2006. Pretoria: Government Printing Works

Department of Education (DoE) (2008c) 2008 School Realities. September 2008.

Department of Education (DoE) (2009b) Education Statistics in South Africa at a glance in 2007. Pretoria: Government Printing Works. Government Printing Works.

Department of Education (DoE) (2009c) 2009 School Realities. September 2009.

Department of Education (DoE) (2007) Student Tuition Fees and the Resourcing of Public Higher Education. Presentation by Professor Ian Bunting to the Task Team, 15 May.

Department of Higher Education \& Training (2010) Report of the Ministerial Committee on the Review of the National Student Financial Aid Scheme. Pretoria.

Higher Education South Africa (HESA) (2008) Tuition fees: higher education institutions in South Africa. Available at: http://www.hesa.org.za/resources/HESA\%20TT\%20Report\%20\%20$\% 2027 \% 20 \mathrm{Feb} \% 202008 \% 20(2)$.pdf.

Hughes, R. (1994) Legitimation, Higher Education, and the Post-Colonial State: A Comparative Study of India and Kenya. Comparative Education, Vol. 30 (3) 193-204. 
Johstone and Marcucci (2010) Financing Higher Education Worldwide: Who Pays? Who Should Pay? Johns Hopkins University Press: Baltimore

Letseka, M., Cosser, M., Breier, M. \& Visser, M. Student retention and graduate destination: higher education and labour market access and success. Cape Town: HSRC Press.

Makulu, H,F (1971) Education, Development and Nation-building in Independent Africa. SCM Press: London.

Mamdani, M. (2006). Higher education, the state and the marketplace. Paper presented at the 16th Conference of Commonwealth Education Ministers (16CCEM), Cape Town, 11-14 December.

National Planning Commission (2011) Diagnostic Overview. The Presidency: Pretoria.

Ouma, G. W. (2007). Reducing resource dependence on government funding: The case of public universities in Kenya and South Africa. Unpublished PhD dissertation, University of Cape Town.

Steyn, G. and de Villiers P. (2006) The impact of changing funding sources on higher education institutions in South Africa. Pretoria. the Council on Higher Education.

Taylor, S. \& Yu, D. (2009) socio-economic status and educational Achievement: does education provide a stepping stone out of poverty in South Africa? In: J. Hofmeyr (Ed.) Recession and Recovery: 2009 Transformation Audit. Institute for Justice and Reconciliation: Cape Town. Pp. 66-75.

Teal, F. (2010) Higher education and economic development in Africa: A review of channels of interaction and evidence. Paper presented at the 32nd African Economic Research Consortium (AERC) Biannual Research Workshop on Higher Education and Economic Development, May 29 June 32010 in Mombasa, Kenya.

Teixeira, P.N., Johnstone, D.B., Rosa, M.J. and Vossensteyn, H. (Eds) (2006) Cost-sharing and accessibility in higher education: a fairer deal? Springer: Dordrecht.

Van der Berg, S (2002) Paper prepared for the conference of the Centre for the Study of African Economies on Economic growth and poverty in Africa. Oxford, March 2002.

Van der Berg, S (2007) Apartheid's Enduring Legacy: Inequalities in Education. Journal of African Economies, Vol. 16 (5), 849-880.

Van der Berg, S (2008) How effective are poor schools? Poverty and educational outcomes in South Africa. Discussion paper number 68. Centre for European, Governance and Economic Development Research. Georg-August-Universitat Gottingen.

Wangenge-Ouma, G (2010) Funding and the attainment of transformation goals in South Africa's higher education. Oxford Review of Education.Vol. 36 (4), 481 - 497. 
Wangenge-Ouma (2008) Globalisation and higher education funding policy shifts in Kenya. Journal of Higher Education Policy and management. Vol. 30 (3), 215-229

Wangenge-Ouma, G. and Cloete, N. (2008) Financing higher education in South Africa: public funding, non-government revenue and tuition fees, South African Journal of Higher Education, 22, 4, 906 - 919.

Zumeta, W. (2004) State Higher Education Financing: Demand Imperatives Meet Structural, Cyclical, and Political Constraints, in St. John, E.P. and Parsons, M.D. (eds.). Public Funding of Higher Education: Changing Contexts and New Rationales, Baltimore: The Johns Hopkins University Press, pp. 79 - 107. 